\title{
Zn(II) Coordination by Open-chain Polyamine Ligands Containing Dipyridine Units. Highly Active Dinuclear Zn(II) Complexes in Phosphate Ester Hydrolysis
}

\author{
Carla Bazzicalupi, Andrea Bencini*, Andrea Danesi, Enrico Faggi, Claudia Giorgi, Costanza \\ Ravagli and Barbara Valtancoli
}

Department of Chemistry, University of Florence, Via della Lastruccia 3, 50019-Sesto Fiorentino, Firenze, Italy

\begin{abstract}
The synthesis and characterization of two new open-chain ligands, $\mathbf{L 1}$ and L2, containing two 2,2'-dipyridine units connected respectively by a pentaethylenhexamine and a pentapropylenhexamine chain, is reported. Zn(II) complexation has been studied by means of potentiometric and UV-vis spectrophotometric measurements in aqueous solution. Both ligands form stable mono- and dinuclear complexes, the metal ions being coordinated by a single dipyridine unit and by the adjacent amine groups. The ability of the binuclear $\mathrm{Zn}(\mathrm{II})$ complexes as nucleophilic agents in hydrolytic processes has been tested by using bis( $p$-nitrophenyl) phosphate (BNPP) as substrate. Both complexes display high rate enhancements in BNPP cleavage in aqueous solution. The study outlines that different mechanisms are operative in BNPP cleavage in the presence of the $\mathbf{L} \mathbf{1}$ and $\mathbf{L} \mathbf{2}$ complexes.
\end{abstract}

Keywords: Phosphate ester hydrolysis, macrocycles, zinc complexes, zinc enzyme models, polyamine ligands, stability constants of complexes.

\section{INTRODUCTION}

Over the years a great deal of interest has been focused on the role of metal ions in the active centers of hydrolytic metalloenzymes [1-11]. Many hydrolytic enzymes, including those which hydrolyze the phosphate ester bond, contain a couple of $\mathrm{Zn}$ (II) ions in their active site, which act cooperatively in the catalytic process. This metal can exchange ligands very rapidly and can form stable intermediate complexes with the targeted substrates. At the same time, $\mathrm{Zn}(\mathrm{II})$ is also able to assist in Lewis activation, nucleophile generation and leaving group stabilization. All these characteristics make zinc sites ideal for catalysis of hydrolytic reactions. The catalytic site can be lodged in a hydrophobic pocket, which may contribute to substrate binding and can also assist the formation of the nucleophilic $\mathrm{Zn}(\mathrm{II})-\mathrm{OH}$ functions.

Polyamine ligands containing six or more nitrogen donors and cavities of appropriate shape and dimension may be able to hold two metal centers at short distances [12-29]. The distance between the two metal ions can be varied by an opportune synthetic modulation of the structural characteristics of the ligands. At the same time, the chemical properties of the metal centers depend on the ligational properties of the chelating sites. Therefore, an appropriate design of the metal binding unit may lead to polynuclear metal complexes with different reactivity and catalytic properties.

For these reasons, several dinuclear metal complexes with polyamine ligands have been used to mimic the

*Address correspondence to this author at the Department of Chemistry, University of Florence, Via della Lastruccia 3, 50019-Sesto Fiorentino, Firenze, Italy; Tel: +39-055-4573371; Fax: +39-055-4573364;

E-mail: andrea.bencini@unifi.it multinuclear metal arrays at the active sites of hydrolytic metallo-enzymes [30-70].

We have recently reported on mono- and dinuclear $\mathrm{Zn}$ (II) complexes with macrocyclic polyamine ligands containing 2,2'-dipyridine, such as $\mathbf{1}$ and $\mathbf{2}$ in Scheme $\mathbf{1}$, able to hydrolyze the phosphate ester bond of activated substrates, such as bis(p-nitrophenyl)phosphate (BNPP) [71]. This study pointed out that the hydrolytic mechanism occurs through interaction of the anionic phosphate moiety with the $\mathrm{Zn}$ (II) centers and simultaneous attack of a nucleophilic $\mathrm{Zn}-\mathrm{OH}$ function to phosphorous.

It was also suggested that the heteroaromatic moieties may reinforce the overall interaction between BNPP and the metal complex, thanks to $\pi$-stacking and/or hydrophobic interactions with the $p$-nitrophenylene units of this substrate, leading to a marked increase of its hydrolysis rate. We have now synthesized ligands L1 and L2 (Scheme 1), which contain two dipyridine moieties attached, as lateral side arms, to a hexadentate open-chain polyamine scaffold. These ligands present a more flexible backbone with respect to macrocyclic ligands. This, in principle, can influence their binding features toward metal cations as well as the hydrolytic properties toward BNPP. We report here on the coordination properties of the ligands toward $\mathrm{Zn}$ (II) and on the ability of the $\mathrm{Zn}$ (II) complexes to cleave the phosphate ester bond, by using bis( $p$-nitrophenyl) phosphate (BNPP) as substrate.

\section{RESULTS AND DISCUSSION}

\section{Zn(II) Complexation in Aqueous Solution}

Protonation and coordination properties of the ligands toward $\mathrm{Zn}(\mathrm{II})$ have been studied in $0.1 \mathrm{M} \mathrm{NMe}_{4} \mathrm{Cl}$ aqueous solutions by means of potentiometric and UV-vis measurements. The protonation constants of the ligands are in the 


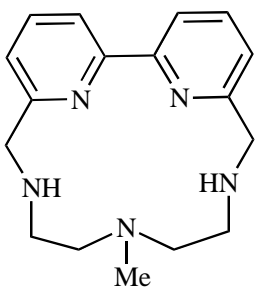

1

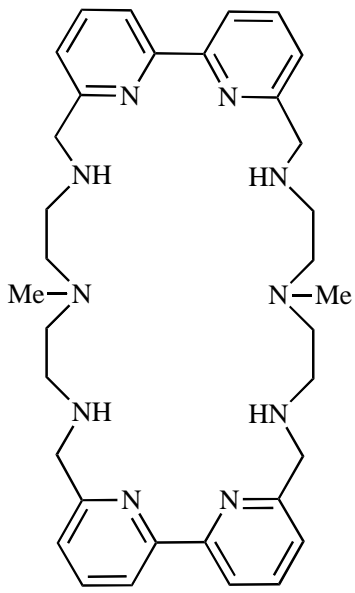<smiles>CC(C)CNCCC(C)CNCc1cccc(-c2ccccn2)n1</smiles><smiles>CC(C)(C)CCNCC(C)(C)NCc1cccc(CNCc2cccc(-c3ccccn3)n2)n1</smiles>

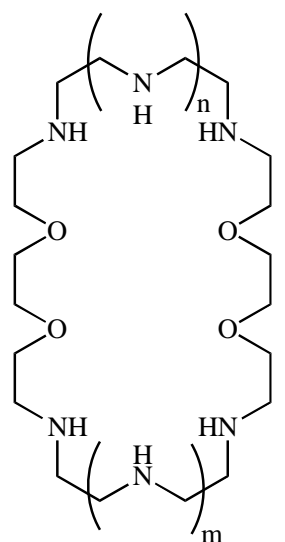

$\mathrm{n}=1, \mathrm{~m}=13$

$\mathrm{n}=1, \mathrm{~m}=2 \quad 4$

$\mathrm{n}=2, \mathrm{~m}=25$
Scheme 1. Ligand drawings.

range generally observed for polyamine ligands [72, ${ }^{\#}$ Table 1 collects the stability constants of $\mathrm{Zn}$ (II) complexes potentiometrically determined. Both ligands form mono- and binuclear $\mathrm{Zn}(\mathrm{II})$ complexes.

Considering the formation constants of the $1: 1$ complexes with $\mathrm{Zn}$ (II), the data in Table 1 outline that both ligands give remarkably stable complexes with this metal. For instance, the stability of the $\mathbf{L 1}$ complex is similar to that found for the corresponding complex with the linear hexadentate polyamine 1,4,7,10,13,16-hexaazahexadecane (L3) $(\operatorname{LogK}=$ 17.46 and 16.96 for the formation of the $[\mathrm{ZnL1}]^{2+}$ and $[\mathrm{ZnL3}]^{2+}$ complexes, respectively), which contains six amine groups separated by ethylenic chains, for which it was proposed that $\mathrm{Zn}(\mathrm{II})$ could be bound to six amine groups [73]. At the same time, L1 shows a higher binding ability for $\mathrm{Zn}$ (II) than $\mathbf{L 2}$ ( $\operatorname{LogK}=17.46$ and 15.13 for the formation of $[\mathrm{ZnL} 1]^{2+}$ and $[\mathrm{ZnL2}]^{2+}$, respectively). The lower stability of the $\mathbf{L} 2$ complexes can be simply attributed to the replacement of the ethylenic chains that link the aliphatic amine donors by propylenic chains. In fact, the increased $\mathrm{N}-\mathrm{Zn}-\mathrm{N}$

"Protonation constants of L1: $\log K_{1}=9.73(1), \log K_{2}=8.64(1), \log K_{3}=7.89(1)$, $\operatorname{LogK}_{4}=6.26(1), \operatorname{LogK}_{5}=4.35(1), \log _{6}=3.97(1), \operatorname{LogK}_{7}=3.35(1), \operatorname{LogK}_{8}=2.75(1)$; Protonation constants of $\mathbf{L 2}: \log K_{1}=10.27(1), \log K_{2}=9.80(1), \log _{3}=8.62(1)$, $\log K_{4}=7.72(1), \log _{5}=7.10(1), \log K_{6}=6.58(1), \log K_{7}=4.30(1), \log K_{8}=3.66(1)$. $\mathrm{K}_{\mathrm{x}}$ refers to the equilibrium $\mathrm{LH}_{\mathrm{x}-1}(\mathrm{x}-1)++\mathrm{H}^{+}=\mathrm{LH}_{\mathrm{x}}^{\mathrm{x}}(\mathrm{L}=\mathbf{L} \mathbf{1}$ or $\mathbf{L 2})$. bond angle, as a result of the larger bite of the propylenic chains, reduces the stability of the complexes [26].

Furthermore, the $[\mathrm{ZnL}]^{2+}$ complexes $(\mathrm{L}=\mathbf{L 1}$ or $\mathbf{L 2})$ display a high tendency to bind acidic protons in aqueous solutions affording up to tetra- or pentaprototonated complexes. As shown in Fig. (1) for $\mathrm{Zn}$ (II) complexation with $\mathbf{L 2}$, the metal is bound at acidic $\mathrm{pH}$ values to afford $\left[\mathrm{ZnH}_{\mathrm{x}} \mathbf{L 2}\right]^{(\mathrm{x}+2)+}$ species; the $[\mathrm{ZnL} \mathbf{L}]^{2+}$ complex is then formed at alkaline $\mathrm{pH}$ values.

This marked tendency of the $[\mathrm{ZnL}]^{2+}$ complexes to protonate can be ascribed to the presence of amine groups not involved in metal coordination. These donors, therefore, are available for coordination of a second $\mathrm{Zn}$ (II) ion. Actually, both $\mathbf{L} 1$ and $\mathbf{L 2}$ can give stable dinuclear Zn(II) complexes, which are largely prevalent in aqueous solutions containing the metal and $\mathbf{L 1}$ or $\mathbf{L} \mathbf{2}$ in 2:1 molar ratio from slightly acidic to alkaline $\mathrm{pH}$ values (see Fig. 2 for $\mathrm{Zn}$ (II) complexation with L2).

In particular, the formation of binuclear protonated complexes $\left[\mathrm{Zn}_{2} \mathrm{H}_{\mathrm{x}} \mathrm{L}\right]^{(\mathrm{x}+4)+}(\mathrm{x}=1$ or $2, \mathrm{~L}=\mathbf{L 1}$ or $\mathbf{L 2})$ as well as of the $\left[\mathrm{Zn}_{2} \mathrm{~L}\right]^{4+}$ species occurs at acidic $\mathrm{pH}$ values and is followed by the formation of a monohydroxo species $\left[\mathrm{Zn}_{2} \mathrm{~L}(\mathrm{OH})\right]^{3+}$ at neutral or slightly alkaline $\mathrm{pH}$ values. Fi- 
nally, the formation of a dihydroxo complex, $\left[\mathrm{Zn}_{2} \mathrm{~L}(\mathrm{OH})_{2}\right]^{2+}$, takes place in the alkaline $\mathrm{pH}$ region.

Table 1. Stability Constants of the $\mathrm{Zn}$ (II) Complexes with L1 and $\mathrm{L} 2\left(\mathrm{NMe}_{4} \mathrm{Cl} 0.1 \mathrm{M}, 308 \mathrm{~K}\right)$

\begin{tabular}{|c|c|}
\hline Reaction & $\log K$ \\
\hline $\mathbf{L} \mathbf{1}+\mathrm{Zn}^{2+}=[\mathrm{Zn} \mathbf{L} \mathbf{1}]^{2+}$ & $17.46(2)$ \\
\hline$[\mathrm{ZnL1} 1]^{2+}+\mathrm{H}^{+}=[\mathrm{ZnHL1}]^{3+}$ & $8.75(1)$ \\
\hline$[\mathrm{ZnHL1}]^{3+}+\mathrm{H}^{+}=\left[\mathrm{ZnH}_{2} \mathbf{L} \mathbf{1}\right]^{4+}$ & $6.06(1)$ \\
\hline$\left[\mathrm{ZnH}_{2} \mathbf{L} \mathbf{1}\right]^{4+}+\mathrm{H}^{+}=\left[\mathrm{ZnH}_{3} \mathbf{L 1}\right]^{5+}$ & $3.51(3)$ \\
\hline$\left[\mathrm{ZnH}_{3} \mathbf{L} \mathbf{1}\right]^{5+}+\mathrm{H}^{+}=\left[\mathrm{ZnH}_{4} \mathbf{L 1}\right]^{6+}$ & $3.32(3)$ \\
\hline$\left[\mathrm{ZnH}_{4} \mathbf{L} \mathbf{1}\right]^{6+}+\mathrm{H}^{+}=\left[\mathrm{ZnH}_{5} \mathbf{L} \mathbf{1}\right]^{7+}$ & 2.94(3) \\
\hline$[\mathrm{ZnL1}]^{2+}+\mathrm{OH}^{-}=[\mathrm{Zn} \mathbf{L 1}(\mathrm{OH})]^{+}$ & $2.20(3)$ \\
\hline $\mathbf{L} \mathbf{1}+2 \mathrm{Zn}^{2+}=\left[\mathrm{Zn}_{2} \mathbf{L} \mathbf{1}\right]^{4+}$ & $29.87(4)$ \\
\hline$\left[\mathrm{Zn}_{2} \mathbf{L} \mathbf{1}\right]^{4+}+\mathrm{H}^{+}=\left[\mathrm{Zn}_{2} \mathrm{HL} \mathbf{1}\right]^{5+}$ & $4.83(2)$ \\
\hline$\left[\mathrm{Zn}_{2} \mathrm{HL1}\right]^{5+}+\mathrm{H}^{+}=\left[\mathrm{Zn}_{2} \mathrm{H}_{2} \mathbf{L} \mathbf{1}\right]^{6+}$ & $2.94(2)$ \\
\hline$\left[\mathrm{Zn}_{2} \mathbf{L 1}\right]^{4+}+\mathrm{OH}^{-}=\left[\mathrm{Zn}_{2} \mathbf{L 1}(\mathrm{OH})\right]^{3+}$ & $4.43(2)$ \\
\hline$\left[\mathrm{Zn}_{2} \mathbf{L} \mathbf{1}(\mathrm{OH})\right]^{3+}+\mathrm{OH}^{-}=\left[\mathrm{Zn}_{2} \mathbf{L} \mathbf{1}(\mathrm{OH})_{2}\right]^{2+}$ & $3.18(4)$ \\
\hline$\left[\mathrm{Zn}_{2} \mathbf{L 1}\right]^{4+}+\mathrm{H}_{2} \mathrm{O}=\left[\mathrm{Zn}_{2} \mathbf{L} \mathbf{1}(\mathrm{OH})\right]^{3+}+\mathrm{H}^{+}$ & $-8.97(2)$ \\
\hline$\left[\mathrm{Zn}_{2} \mathbf{L 1}(\mathrm{OH})\right]^{3+}+\mathrm{H}_{2} \mathrm{O}=\left[\mathrm{Zn}_{2} \mathbf{L} \mathbf{1}(\mathrm{OH})_{2}\right]^{2+}+\mathrm{H}^{+}$ & $-10.22(4)$ \\
\hline $\mathbf{L} 2+\mathrm{Zn}^{2+}=[\mathrm{Zn} \mathbf{L} 2]^{2+}$ & $15.13(1)$ \\
\hline$[\mathrm{ZnL} \mathbf{2}]^{2+}+\mathrm{H}^{+}=[\mathrm{ZnHL} 2]^{3+}$ & $9.35(1)$ \\
\hline$[\mathrm{ZnHL2}]^{3+}+\mathrm{H}^{+}=\left[\mathrm{ZnH}_{2} \mathbf{L} 2\right]^{4+}$ & $8.15(2)$ \\
\hline$\left[\mathrm{ZnH}_{2} \mathbf{L} 2\right]^{4+}+\mathrm{H}^{+}=\left[\mathrm{ZnH}_{3} \mathbf{L} 2\right]^{5+}$ & $7.67(2)$ \\
\hline$\left[\mathrm{ZnH}_{3} \mathbf{L} 2\right]^{5+}+\mathrm{H}^{+}=\left[\mathrm{ZnH}_{4} \mathbf{L} 2\right]^{6+}$ & $5.66(3)$ \\
\hline$\left[\mathrm{ZnH}_{4} \mathbf{L} 2\right]^{6+}+\mathrm{H}^{+}=\left[\mathrm{ZnH}_{5} \mathbf{L} \mathbf{2}\right]^{7+}$ & $4.16(4)$ \\
\hline$[\mathrm{ZnL2}]^{2+}+\mathrm{OH}^{-}=[\mathrm{ZnL} \mathbf{2}(\mathrm{OH})]^{+}$ & $3.71(2)$ \\
\hline $\mathbf{L} \mathbf{2}+2 \mathrm{Zn}^{2+}=\left[\mathrm{Zn}_{2} \mathbf{L} 2\right]^{4+}$ & $24.02(3)$ \\
\hline$\left[\mathrm{Zn}_{2} \mathbf{L} 2\right]^{4+}+\mathrm{H}^{+}=\left[\mathrm{Zn}_{2} \mathrm{HL} \mathbf{2}\right]^{5+}$ & $5.90(3)$ \\
\hline$\left[\mathrm{Zn}_{2} \mathrm{HL} \mathbf{L}\right]^{5+}+\mathrm{H}^{+}=\left[\mathrm{Zn}_{2} \mathrm{H}_{2} \mathbf{L} 2\right]^{6+}$ & $5.04(4)$ \\
\hline$\left[\mathrm{Zn}_{2} \mathbf{L} 2\right]^{4+}+\mathrm{OH}^{-}=\left[\mathrm{Zn}_{2} \mathbf{L} \mathbf{2}(\mathrm{OH})\right]^{3+}$ & $6.09(3)$ \\
\hline$\left[\mathrm{Zn}_{2} \mathbf{L} \mathbf{2}(\mathrm{OH})\right]^{3+}+\mathrm{OH}^{-}=\left[\mathrm{Zn}_{2} \mathbf{L} \mathbf{2}(\mathrm{OH})_{2}\right]^{2+}$ & $3.56(3)$ \\
\hline$\left[\mathrm{Zn}_{2} \mathbf{L} 2\right]^{4+}+\mathrm{H}_{2} \mathrm{O}=\left[\mathrm{Zn}_{2} \mathbf{L} 2(\mathrm{OH})\right]^{3+}+\mathrm{H}^{+}$ & $-7.31(3)$ \\
\hline$\left[\mathrm{Zn}_{2} \mathbf{L 2}(\mathrm{OH})\right]^{3+}+\mathrm{H}_{2} \mathrm{O}=\left[\mathrm{Zn}_{2} \mathbf{L} 2(\mathrm{OH})_{2}\right]^{2+}+\mathrm{H}^{+}$ & $-9.84(3)$ \\
\hline
\end{tabular}

The process of metal complexation was also investigated by means of UV spectrophotometric measurements. 2,2'Dipyridine, in fact, is characterized by an absorption band at $288 \mathrm{~nm}$. Zn(II) binding by dipyridine leads to the disappearance of the UV band at $288 \mathrm{~nm}$ and to the formation of a new red-shifted absorption band at $c a .310 \mathrm{~nm}$. The appearance of this band can be used as diagnostic tool to detect metal binding to the dipyridine unit in solution. As shown in Fig. (3) for the system $\mathrm{Zn}(\mathrm{II}) / \mathbf{L} 2$, addition of increasing

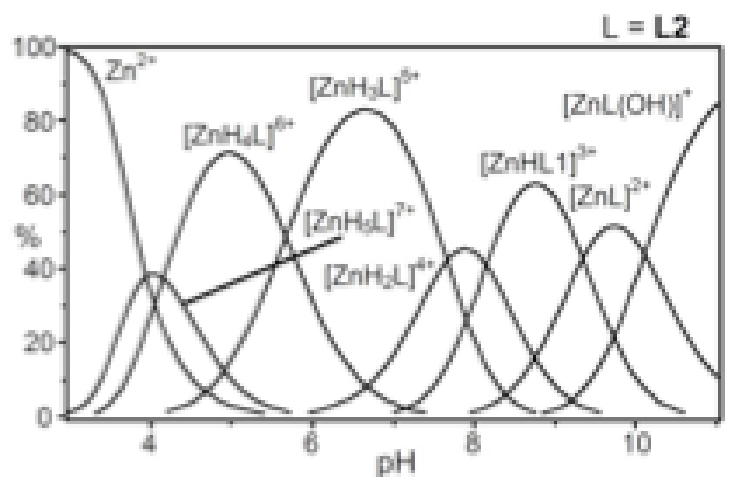

Fig. (1). Species distribution diagrams for the system $\mathrm{Zn}(\mathrm{II}) / \mathbf{L} 2$ in $1: 1$ molar ratio $\left([\mathbf{L 2}]=1 \times 10^{-3} \mathrm{M}, I=0.1 \mathrm{M}, 308 \mathrm{~K}\right)$.

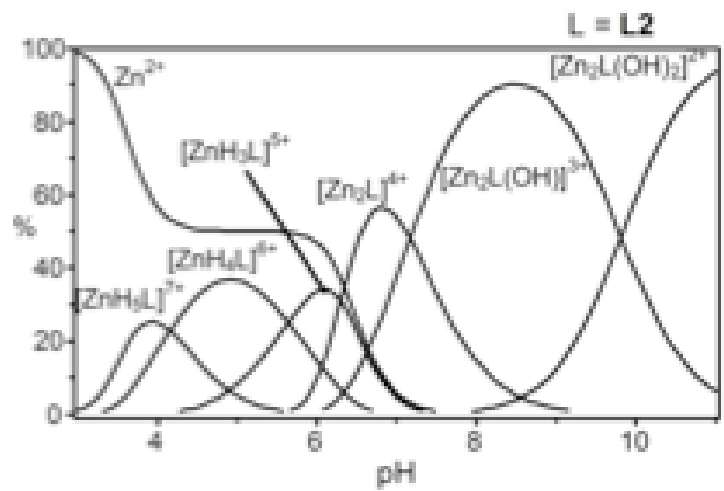

Fig. (2). Species distribution diagrams for the system $\mathrm{Zn}(\mathrm{II}) / \mathbf{L} 2$ in 2:1 molar ratio $\left([\mathbf{L 2}]=1 \times 10^{-3} \mathrm{M}, I=0.1 \mathrm{M}, 308 \mathrm{~K}\right)$.

amounts of $\mathrm{Zn}$ (II) to an aqueous solution of the ligand buffered at $\mathrm{pH} 9$ leads to the appearance of a new structured band at $c a 310 \mathrm{~nm}$ and to the disappearance of the band at $288 \mathrm{~nm}$. Almost equal spectral changes were also observed upon addition of $\mathrm{Zn}(\mathrm{II})$ to solutions of $\mathbf{L 1}$. The absorbance measured at $313 \mathrm{~nm}$ increases linearly up to $1.75: 1 \mathrm{Zn}$ (II) to L2 molar ratio, to achieve a constant value for molar ratios greater than 2.25 (Fig. 3b), indicating the formation of stable 1:2 complexes (see below). The observed linear increase of the absorbance at $313 \mathrm{~nm}$ up to the addition of $1.75 \mathrm{eq}$ of the metal strongly suggests that the process of metal binding takes place through coordination of a first metal ion by a single dipyridine unit with M:L molar ratio lower than 1, followed by binding of the second metal to the remaining dipyridine moiety with M:L molar ratio greater than 1 .

Of note, $\mathbf{L} \mathbf{1}$ gives rise to the formation of more stable dinuclear complexes than $\mathbf{L 2}(\log \mathrm{K}=29.87$ and 24.02 for the equilibrium $\mathrm{L}+2 \mathrm{Zn}^{2+}=\left[\mathrm{Zn}_{2} \mathrm{~L}\right]^{4+}$ with $\mathrm{L}=\mathbf{L} \mathbf{1}$ and $\mathbf{L 2}$, respectively), in keeping with the higher binding ability toward $\mathrm{Zn}(\mathrm{II})$ generally observed with polydentate ligands containing ethylene spacers between amine donors. Most likely, in the $\mathbf{L} \mathbf{1}$ complex the metals achieve a coordination sphere more saturated by the ligand donors than in the $\mathbf{L 2}$ one. However, in both the dinuclear complexes with $\mathbf{L 1}$ and L2 deprotonation of $\mathrm{Zn}(\mathrm{II})$-coordinated water molecules gives mono- and dihydroxo-species. At the same time, the dinuclear complex with $\mathbf{L 2}$ displays a higher tendency to give hydroxo-species than the corresponding $\mathbf{L} 1$ one, in 


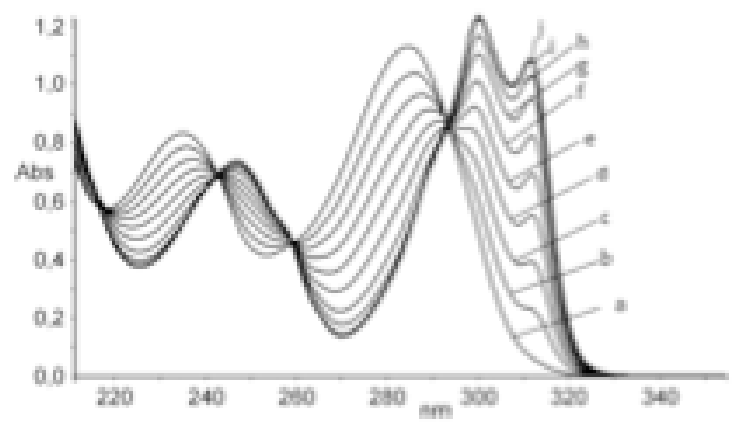

a

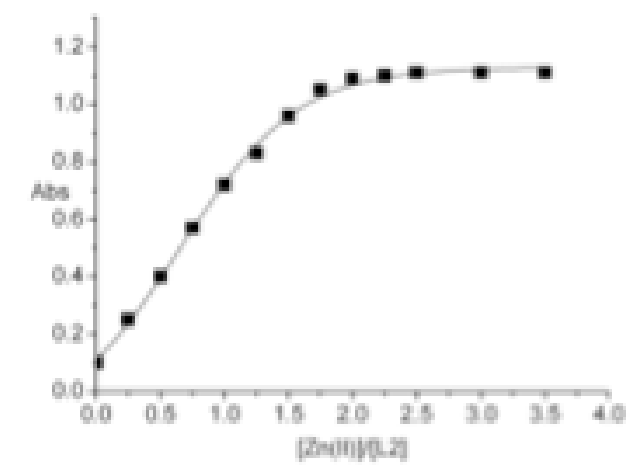

Fig. (3). (a) UV spectra of $\mathbf{L} 2$ in the presence of increasing amounts of $\mathrm{Zn}(\mathrm{II})([\mathrm{Zn}(\mathrm{II})] / \mathbf{L} 2$ molar ratio: 0 (a); 0.25, (b); 0.5 (c); 0.75 (d); 1 (e); 1.25 (f); 1.5 (g); 1.75 (h), 2 (i), 2.25 (j), [L2] = 5 x $\left.10^{-5} \mathrm{M}, \mathrm{I}=0.1 \mathrm{M}\right)$. (b) Absorbance at $313 \mathrm{~nm}$ of $\mathbf{L} \mathbf{2}$ in the presence of increasing amounts of $\mathrm{Zn}(\mathrm{II})$.

keeping with the proposed lower number of ligand donors involved in metal coordination in the $\mathbf{L 2}$ complex. For instance, the $\mathrm{pK}_{\mathrm{a}}$ value for deprotonation of the first water molecule in $\left[\mathrm{Zn}_{2} \mathbf{L 2}\right]^{4+}$ to give $\left[\mathrm{Zn}_{2} \mathbf{L 2}(\mathrm{OH})\right]^{3+}$ is rather low when compared to the corresponding $\mathbf{L} \mathbf{1}$ complex $\left(\mathrm{pK}_{\mathrm{a}}=\right.$ 7.31 and 8.97 for $\left[\mathrm{Zn}_{2} \mathbf{L} \mathbf{2}\right]^{4+}$ and $\left[\mathrm{Zn}_{2} \mathbf{L 1}\right]^{4+}$, respectively). Similar low values are generally attributed, in dinuclear $\mathrm{Zn}$ (II) complexes, to a bridging coordination of the hydroxide anion between two metal centres [46-49]. Most likely, in $\left[\mathrm{Zn}_{2} \mathbf{L 2}\right]^{4+}$ the two metals may achieve a short intermetallic distance, thanks to the higher overall flexibility conferred to the ligand by the presence of propylenic chains, more flexible than the ethylenic ones of L1. This could favor the assembly of a $\mathrm{Zn}_{2}(\mu-\mathrm{OH})$ unit enveloped within the ligand backbone. The $\mathrm{pK}_{\mathrm{a}}$ value (9.84 log units) for the formation of the dihydroxo-complex $\left[\mathrm{Zn}_{2} \mathbf{L 2}(\mathrm{OH})_{2}\right]^{2+}$ is too high to be ascribed to a bridging hydroxide anion. Indeed, the bridging hydroxide anion in the monohydroxo-complex $\left[\mathrm{Zn}_{2} \mathbf{L 2}(\mathrm{OH})\right]^{3+}$ reduces the positive charge on the metals. This could determine the higher $\mathrm{pK}_{\mathrm{a}}$ value found for deprotonation of a $\mathrm{Zn}(\mathrm{II})$-bound water molecule to give the $\left[\mathrm{Zn}_{2} \mathbf{L 2}(\mathrm{OH})_{2}\right]^{2+}$ complex.

Similarly, the $\mathrm{pK}_{\mathrm{a}}$ values for successive deprotonation of two $\mathrm{Zn}(\mathrm{II})$-bound water molecules in the $\left[\mathrm{Zn}_{2} \mathbf{L 1}\right]^{4+}$ complex to give $\left[\mathrm{Zn}_{2} \mathbf{L 1}(\mathrm{OH})\right]^{3+}\left(\mathrm{pK}_{\mathrm{a}}=8.97\right)$ and $\left[\mathrm{Zn}_{2} \mathbf{L 1}(\mathrm{OH})_{2}\right]^{2+}\left(\mathrm{pK}_{\mathrm{a}}\right.$ $=10.22$ ), can be related to the formation of single-metal bound hydroxide functions. It is reasonable that the higher rigidity of the L1 ligand does not allow the two metals to achieve an intermetallic distance short enough to simultaneously bind to a single hydroxide anion.

The dinuclear $\mathrm{Zn}(\mathrm{II})$ complexes with $\mathbf{L} \mathbf{1}$ and $\mathbf{L 2}$ meet the necessary requisites to be used as functional model systems for hydrolytic enzymes. In fact, facile deprotonation of metal-bound water molecules occurs at neutral or slightly alkaline $\mathrm{pH}$ values to give $\mathrm{Zn}(\mathrm{II})-\mathrm{OH}$ groups, potential nucleophilic agents in hydrolytic processes. At the same time, $\mathbf{L 1}$ and $\mathbf{L 2}$ are capable of holding two metal centers in proximity one to another. From this point of view, the dinuclear complex with $\mathbf{L} 2$ seems to be the most promising hydrolytic system; in this complex, in fact, the ligand flexibility may allow the two metals to achieve the optimal distance to simultaneously interact with substrate molecule or anions. With this in mind, we decided to investigate the binding properties and the hydrolytic ability of our dizinc complexes toward the phosphate ester bond, using bis( $p$-nitrophenyl) phosphate (BNPP) as substrate.

\section{Binding of BNPP by the Dinuclear Zn(II) Complexes}

Dinuclear zinc complexes with $\mathbf{L 1}$ and $\mathbf{L 2}$, $\left[\mathrm{Zn}_{2} \mathbf{L 1}\right]\left(\mathrm{ClO}_{4}\right)_{4} \cdot 2 \mathrm{H}_{2} \mathrm{O}(\mathbf{6})$ and $\left[\mathrm{Zn}_{2} \mathbf{L 2}\right]\left(\mathrm{ClO}_{4}\right)_{4} \cdot 2 \mathrm{H}_{2} \mathrm{O}$ (7) can be isolated as solid compounds from methanol solutions containing the ligands and $\mathrm{Zn}\left(\mathrm{ClO}_{4}\right)_{2}$ in 1:2 molar ratio. In both cases, attempts to obtain crystals suitable for X-ray analysis failed.

Binding of BNPP to the $\mathrm{Zn}$ (II) complexes 6 and $\mathbf{7}$ was followed by means of ${ }^{31} \mathrm{P}$ NMR spectra recorded on MeOD solutions containing BNPP $\left(1 \cdot 10^{-2} \mathrm{M}\right)$ and the complexes in different molar ratio. Solutions containing BNPP and increasing amounts of the dinuclear complexes display a progressive upfield shift of the BNPP signals (Fig. 4).

In the case of the dizinc complex with L2, 7 (Fig. 4b), the plot of the $\Delta \delta$ (where $\Delta \delta$ is the difference between the chemical shift of BNPP in the presence and in absence of the complex) as a function of the [7]/[BNPP] molar ratio (R) gives a straight line for low $R$ values $(R<0.8)$. Then the slope change almost suddenly to give a straight line parallel to the $x$ axis for $\mathrm{R}>1.2$ (at this point $\Delta \delta=4.2$ ). This behavior indicates the formation of a stable 1:1 complex between the dizinc complex and BNPP. Conversely, addition of increasing amounts of complex 6 to a methanol solution of BNPP shows an almost linear increase of $\Delta \delta$ up to an $\mathrm{R}$ value of $1.8(\mathrm{R}=[\mathbf{6}] /[\mathrm{BNPP}]$ molar ratio) (Fig. 4a). No further upfield shift is observed with $\mathrm{R}>2.4$, when $\Delta \delta$ reaches a constant value of $2.0 \mathrm{ppm}$. This result suggests that the $\mathbf{L 1}$ complex 6 is able to bind two BNPP anions. At the same time, the observed linear increase of $\Delta \delta$ up to $\mathrm{R}=1.8$ strongly suggests that $\mathbf{6}$ contains two well-separated binding sites for BNPP anions, i. e., the two metals act as independent anchoring points for BNPP. Actually, similar binding properties were observed for the dizinc complex with ligand 2 (Scheme 1), which contains two dipyridine units separated by two diethylentriamine chains.

Of note, the upfield shift observed for the formation of the 1:1 BNPP adduct with the L2 complex is by far higher than the shift observed for the formation of the 1:2 BNPP adduct with the $\mathbf{L 1}$ complex. This observation suggests that BNPP is more strongly bound to the dinuclear $\mathbf{L 2}$ complex than to the $\mathbf{L 1}$ one and leads us to speculate that in the ad- 
duct with the L2 complex BNPP interacts simultaneously with both metals, through a bridging coordination mode of the phosphate group.

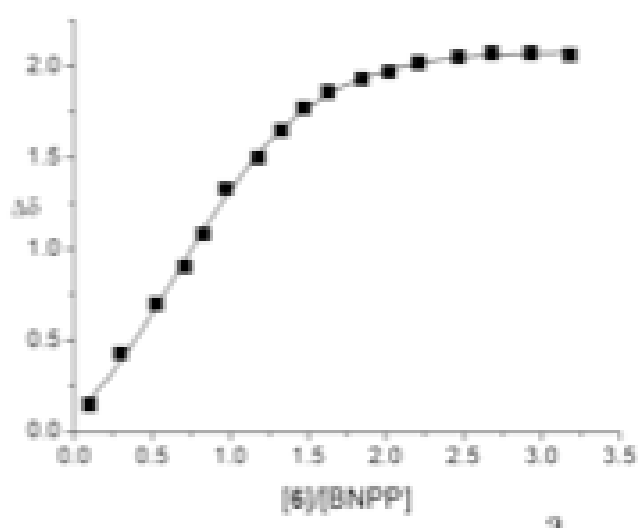

a

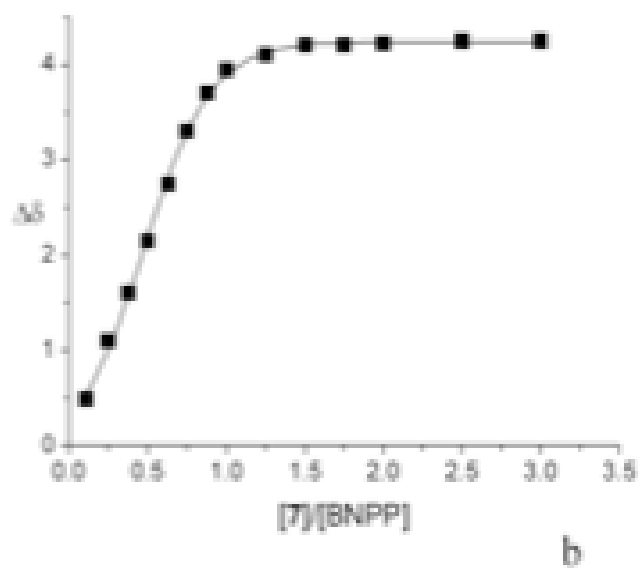

Fig. (4). Plot of the ${ }^{31} \mathrm{P}$ NMR chemical shifts of BNPP $\left(\Delta \delta=\delta_{\mathrm{BNPP}}\right.$ $-\delta_{\mathrm{OBS}}$, where $\delta_{\mathrm{BNPP}}=$ chemical shift of the unbound BNPP ester and $\delta_{\mathrm{OBS}}=$ observed chemical shift in the presence of the $\mathbf{6}$ and $\mathbf{7}$ dinuclear complexes) as a function of the $[6] /[\mathrm{BNPP}]$ (a) and of the [7]/[BNPP] (b) molar ratios $(\mathrm{MeOH}$ solution, [dizinc complex] $=1$ $\left.\cdot 10^{-2} \mathrm{M}\right)$.

The different binding properties of the $\mathbf{L 1}$ and $\mathbf{L 2}$ complexes can be attributed, once again, to the different flexibility of the two ligands in their dinuclear complexes. While in the case of the more flexible complex with $\mathbf{L 2}$ the two metals can achieve an optimal distance to act cooperatively in substrate binding, in the case of the complex with $\mathbf{L 1}$ the rigidity of the ligand makes the two metals unable to attain a short intermetallic distance and therefore they act as independent binding site for BNPP. At the same time, in the L2 complex the metals are less coordinatively saturated by the ligand donors. This can also contribute to the observed higher binding ability for the anionic BNPP substrate.

The ${ }^{31} \mathrm{P}$ NMR spectra recorded in $\mathrm{D}_{2} \mathrm{O}$ solution display minor shifts of the BNPP signal, even in the presence of large excess of the dinuclear complexes $(0.4 \mathrm{ppm}$ and 0.3 ppm in the case of $\mathbf{L} \mathbf{2}$ and $\mathbf{L 1}$, respectively) probably due to a much lower percentage of coordinated BNPP in this more solvating medium.
To get further information on the interaction mode of the BNPP anion with our dizinc complexes, we also recorded ${ }^{1} \mathrm{H}$ NMR spectra on MeOD solutions containing BNPP and increasing amounts of the dinuclear $\mathrm{Zn}(\mathrm{II})$ complexes $\mathbf{6}$ and $\mathbf{7}$. Although the ${ }^{1} \mathrm{H}$ NMR spectra of the $\mathrm{Zn}$ (II) complexes are rather fluxional and do not allow one a correct determination of the ${ }^{1} \mathrm{H}$ chemical shifts, the resonances of the aromatic protons of BNPP (two doublets at 8.01 and $7.21 \mathrm{ppm}(\mathrm{H} 1$ and $\mathrm{H} 2$, see Fig. (5) for atom labeling)) are generally easily recognizable.
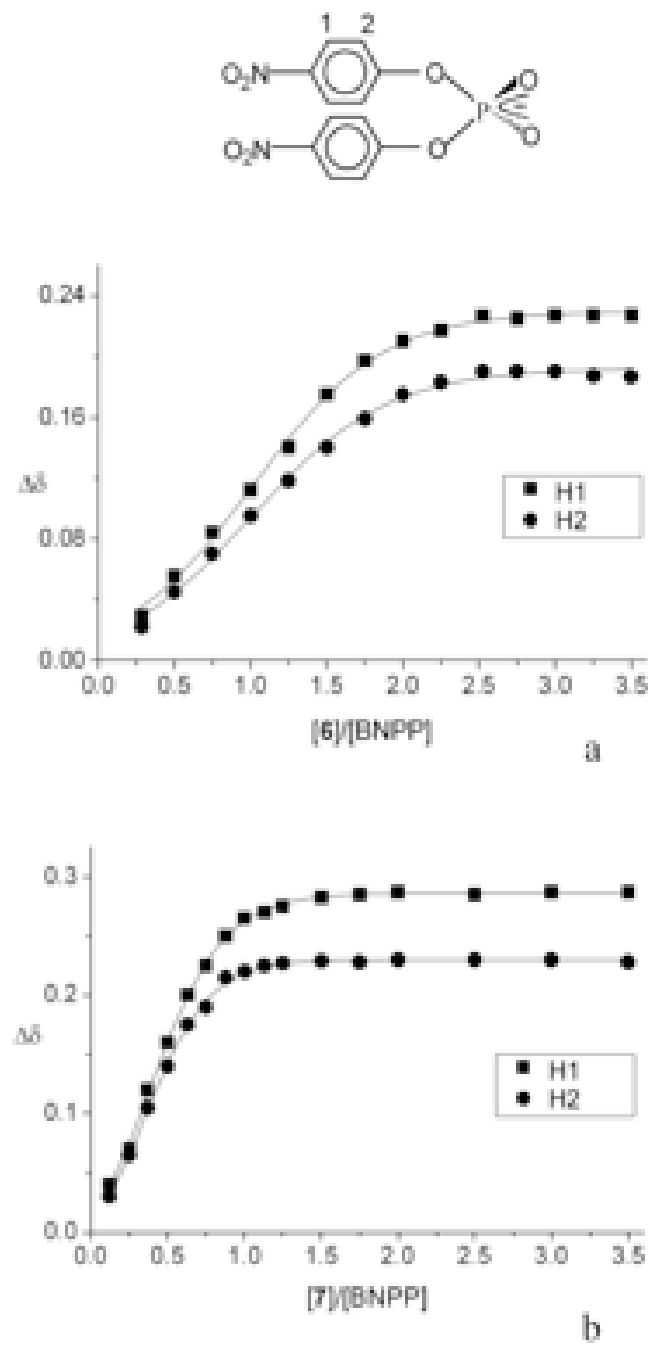

Fig. (5). Plot of the ${ }^{1} \mathrm{H}$ NMR chemical shifts of BNPP $\left(\Delta \delta=\delta_{\mathrm{BNPP}}-\right.$ $\delta_{\mathrm{OBS}}$, where $\delta_{\mathrm{BNPP}}=$ chemical shift of the unbound $\mathrm{BNPP}$ and $\delta_{\mathrm{OBS}}=$ observed chemical shift in the presence of the $\mathbf{6}$ and $\mathbf{7}$ dinuclear complexes) as a function of the $[6] /[\mathrm{BNPP}]$ (a) and [7]/[BNPP]molar ratios (MeOD solution, [dizinc complex] $=1 \cdot 10^{-2}$ $\mathrm{M})$.

Addition of the L1 complex 6 to a BNPP solution gives rise to an upfield shift of both the BNPP signals (Fig. 5a). As in the case of the ${ }^{31} \mathrm{P}$ spectra, the plot of the $\Delta \delta$ values as a function of the $[6] /[\mathrm{BNPP}]$ molar ratio $(\mathrm{R})$ gives a straight line for $\mathrm{R}<1.75$ and subsequently the slope changes to give a straight line parallel to the $x$ axis for $\mathrm{R}>2.25$ (at this point $\Delta \delta=0.22$ and $0.18 \mathrm{ppm}$ for the $\mathrm{H} 1$ and $\mathrm{H} 2$ protons, respectively). 
In the case of the $\mathbf{L} \mathbf{2}$ complex 7, a linear increase of $\Delta \delta$ is instead observed up to $\mathrm{R}=0.75$ (Fig. 5b) and no further shift of the signals is observed for $\mathrm{R}>1.25$ (in this condition $\Delta \delta=$ 0.28 and $0.22 \mathrm{ppm}$ for the $\mathrm{H} 1$ and $\mathrm{H} 2$ protons, respectively). These results are in agreement with the formation of 2:1 and 1:1 adducts between BNPP and the complexes with L1 and L2, respectively. Furthermore, the upfield shifts observed for the BNPP signals suggest the presence of $\pi$-stacking interactions between the aromatic rings of the ester and the dipyridine units. As already proposed on the basis of the ${ }^{31} \mathrm{P} N M R$ study, the larger upfield shifts observed in the ${ }^{1} \mathrm{H}$ NMR spectra of BNPP in the presence of complex 7 account for a stronger interaction between the phosphate ester and the L2 complex with respect to the $\mathbf{L} \mathbf{1}$ one.

\section{$\operatorname{Bis}(p$-nitrophenyl)phosphate Hydrolysis}

The dinuclear $\mathrm{Zn}(\mathrm{II})$ complexes with $\mathbf{L 1}$ and $\mathbf{L 2}$ induce BNPP cleavage to give $p$-nitrophenate (NP) and mono( $p$ nitrophenyl)phosphate (MNPP) (the hydrolysis products were identified by ${ }^{31} \mathrm{P}$ NMR spectroscopy). The formation of inorganic phosphate was not observed in the ${ }^{31} \mathrm{P}$ NMR spectra, even for prolonged reaction times, indicating the MNPP is not further hydrolyzed by the $\mathrm{Zn}$ (II) complexes. Finally, no hydrolytic effect was observed for solutions containing $\mathrm{Zn}$ (II) and $\mathbf{L 1}$ or $\mathbf{L 2}$ in 1:1 molar ratio (in this condition only mononuclear complexes are formed in solution).

The rate constants for BNPP hydrolysis to give MNPP and NP in the presence of the mono- and/or dinuclear complexes with $\mathbf{L 1}$ and $\mathbf{L 2}$ were spectrophotometrically determined at different $\mathrm{pH}$ values by an initial slope method, monitoring the time evolution of the NP band at $403 \mathrm{~nm}$ which allows one to determine rate constant values $\left(k_{\mathrm{BNPP}}\right)$ for BNPP cleavage promoted by the dizinc complexes with L1 and L2. Fig. (6) reports the plots of the rate constant values $\left(k_{\mathrm{BNPP}}\right)$ for the dinuclear $\mathrm{Zn}$ (II) complexes with $\mathbf{L 1}$ and $\mathbf{L 2}$ as a function of $\mathrm{pH}$, superimposed to the corresponding distribution diagrams calculated on the basis of the potentiometric data. For both systems, only hydroxo-complexes promote BNPP cleavage following second order kinetics, while the $\left[\mathrm{Zn}_{2} \mathrm{~L}\right]^{4+}$ species are not active, in agreement with the involvement of a $\mathrm{Zn}-\mathrm{OH}$ function in the cleavage mechanism. Plots of the $k_{\mathrm{BNPP}}$ values as a function of the concentration of the hydroxo-complexes allow one to determine $k_{\text {BNPP }}^{\prime}$ values for $100 \%$ formation of the active species (see experimental section). The active complexes and the corresponding second order rate constants, $k_{\mathrm{BNPP}}^{\text {, }}$ are reported in Table 2. The $k_{\text {BNPP }}$ values for the dinuclear $\mathrm{Zn}$ (II) complexes with macrocycles 1-5 (Scheme 1), are also reported for comparison.

BNPP hydrolysis promoted by mono- and dinuclear $\mathrm{Zn}$ (II) complexes is generally explained in terms of an "associative" mechanism [33-50,71], in which the substrate approaches the $\mathrm{Zn}$ (II) complex and the oxygens of BNPP start associating with the electrophilic $\mathrm{Zn}(\mathrm{II})$ ion. A zincbound hydroxide operates a simultaneous nucleophilic attack to the phosphorus atom. Therefore, the hydrolytic activity of a complex is enhanced by a strong interaction of the BNPP ester with the electrophilic metal centers and by a high nucleophilic character of the $\mathrm{Zn}-\mathrm{OH}$ functions, i. e., by high $\mathrm{pK}_{\mathrm{a}}$ values for the formation of the $\mathrm{Zn}$-bound hydroxide.
Considering the dinuclear $\mathrm{Zn}(\mathrm{II})$ complexes with L2, the plot of the second order rate constants, $k_{\mathrm{BNPP}}$, as a function of $\mathrm{pH}$ points out that only the dihydroxo complex $\left[\mathrm{Zn}_{2} \mathbf{L 2}(\mathrm{OH})_{2}\right]^{2+}$ promotes BNPP hydrolysis in aqueous solution, i. e, $\left[\mathrm{Zn}_{2} \mathbf{L 2}(\mathrm{OH})_{2}\right]^{2+}$ is the kinetically active species (Fig. 6b).
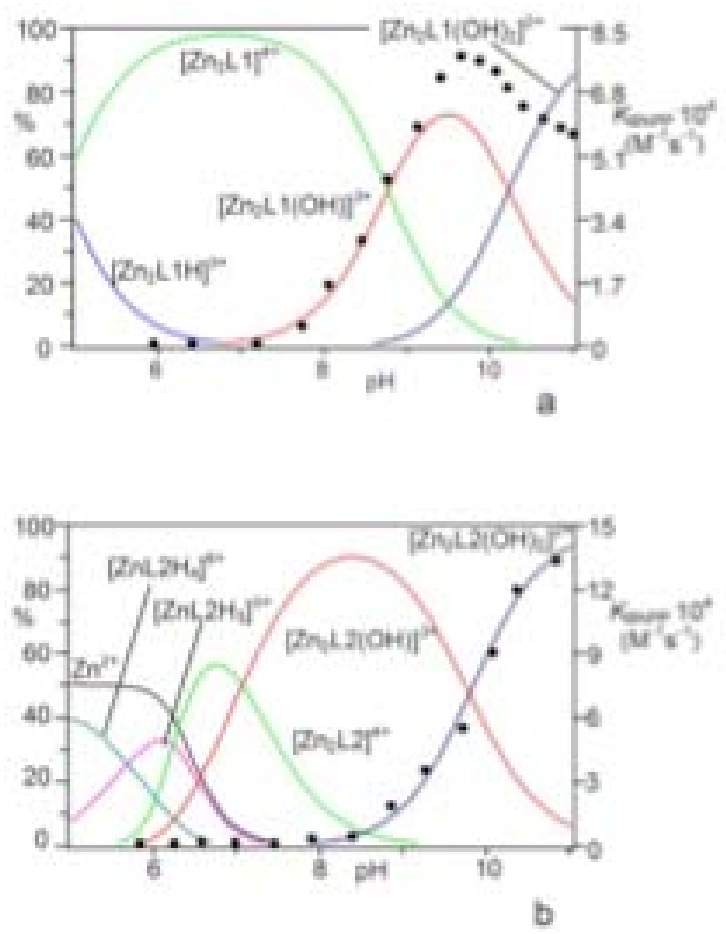

Fig. (6). Plots of the distribution curves of the $\mathrm{Zn}$ (II) complexes with $\mathbf{L 1}$ (a) and L2 (b) (solid line, left Y axes) and $k_{\mathrm{BNPP}}$ values $(\bullet$, right $\mathrm{Y}$ axes) as a function of $\mathrm{pH}$.

Conversely, the monohydroxo complex $\left[\mathrm{Zn}_{2} \mathbf{L 2}(\mathrm{OH})\right]^{3+}$ is totally inactive. As already found with other binucleating ligands, such as 3-5 in Scheme 1 [46,48], the lack of hydrolytic ability of the $\left[\mathrm{Zn}_{2} \mathbf{L} 2(\mathrm{OH})\right]^{3+}$ species can be attributed to a reduced nucleophilicity of the hydroxide function, due to its bridging coordination to two electrophilic metal centers.

Of note, the dinuclear $\mathbf{L 2}$ complex $\left[\mathrm{Zn}_{2} \mathbf{L 2}(\mathrm{OH})_{2}\right]^{2+}$ exhibits a remarkably higher hydrolytic ability than the mononuclear complex $[\mathrm{Zn}(\mathbf{1})(\mathrm{OH})]^{+}$(Table 2) [71]. This behavior cannot be explained in terms of nucleophilic ability of the $\mathrm{Zn}-\mathrm{OH}$ functions, since the $\mathrm{pK}_{a}$ value for the formation of the mononuclear complexes $[\mathrm{Zn}(\mathbf{1})(\mathrm{OH})]^{+}$is by far higher than the $\mathrm{pK}_{a}$ value for the dinuclear $\left[\mathrm{Zn}_{2} \mathbf{L} 2(\mathrm{OH})_{2}\right]^{2+}$ complex, i. e., the $\mathrm{Zn}-\mathrm{OH}$ function is more nucleophile in $[\mathrm{Zn}(\mathbf{1})(\mathrm{OH})]^{+}$than in $\left[\mathrm{Zn}_{2} \mathbf{L 2}(\mathrm{OH})_{2}\right]^{2+}$. The high activity of the $\left[\mathrm{Zn}_{2} \mathbf{L 2}(\mathrm{OH})_{2}\right]^{2+}$ could be explained, instead, by a cooperative role of the two metals in the hydrolytic process, which takes place via a bridging interaction of BNPP, as actually suggested by the ${ }^{31} \mathrm{P}$ NMR measurements. In fact, interaction of the substrate with two electrophilic metal centers favors the nucleophilic attack of a $\mathrm{Zn}-\mathrm{OH}$ function and thus enhances the rate of the hydrolytic process, as already found in several dinuclear synthetic $\mathrm{Zn}(\mathrm{II})$ complexes [3350]. As discussed above, in the dinuclear $\mathbf{L} 2$ complexes the two metals can attain a short intermetallic distance, favoring a bridging interaction mode of the phosphate ester. A sketch 
of the proposed hydrolytic mechanism is shown in Scheme 2 (a).

Table 2. Second-Order Rate Constants $k_{\text {BNPP }}^{\text {' }}\left(M^{-1} \mathrm{~s}^{-1}\right)$ for Hydrolysis of bis( $p$-nitrophenyl) Phosphate and $\mathbf{p K}_{a}$ Values for the Corresponding Hydroxo-Complexes at $308.1 \mathrm{~K}$

\begin{tabular}{|c|c|c|}
\hline Nucleophile & $k_{\mathrm{BNPP}}^{\prime} \times 10^{4}\left(\mathrm{M}^{-1} \mathrm{~s}^{-1}\right)$ & $\mathbf{p K}_{\mathrm{a}}$ \\
\hline$\left[\mathrm{Zn}_{2} \mathbf{L} \mathbf{1}(\mathrm{OH})\right]^{3+}$ & $8.5 \pm 0.8$ & 8.97 \\
\hline$\left[\mathrm{Zn}_{2} \mathbf{L} \mathbf{1}(\mathrm{OH})_{2}\right]^{2+}$ & $5.4 \pm 0.5$ & 10.22 \\
\hline$\left[\mathrm{Zn}_{2} \mathbf{L 2}(\mathrm{OH})\right]^{3+}$ & Not active & 7.31 \\
\hline$\left[\mathrm{Zn}_{2} \mathbf{L 2}(\mathrm{OH})_{2}\right]^{2+}$ & $15 \pm 1.5$ & 9.84 \\
\hline$[\mathrm{Zn}(\mathbf{1})(\mathrm{OH})]^{+\mathrm{a}}$ & 1.1 & 10.73 \\
\hline$\left[\mathrm{Zn}_{2}(\mathbf{2})(\mathrm{OH})\right]^{3+\mathrm{a}}$ & 19.3 & 8.88 \\
\hline$\left[\mathrm{Zn}_{2}(\mathbf{3})(\mathrm{OH})_{2}\right]^{2+\mathrm{b}}$ & 1.15 & 9.2 \\
\hline$\left[\mathrm{Zn}_{2}(\mathbf{4})(\mathrm{OH})_{2}\right]^{2+\mathrm{c}}$ & 0.91 & 9.38 \\
\hline$\left[\mathrm{Zn}_{2}(\mathbf{5})(\mathrm{OH})_{2}\right]^{2+\mathrm{c}}$ & 0.54 & 9.88 \\
\hline
\end{tabular}

${ }^{\mathrm{a}}$ From reference [71]. ${ }^{\mathrm{b}}$ from reference [46]. ${ }^{\mathrm{c}}$ from reference [48].

Of note, the hydrolytic activity of the $\left[\mathrm{Zn}_{2} \mathbf{L} \mathbf{2}(\mathrm{OH})_{2}\right]^{2+}$ is only slightly lower than that reported for the dizinc complex with ligand $\mathbf{2}$ and among the highest observed with binuclear $\mathrm{Zn}$ (II) complexes [71]. For instance, the dizinc complexes with ligands not containing aromatic subunits, such as 3-5 in Scheme 1 [46-48], display a far lower ability in BNPP hydrolysis. These results suggest that the insertion of dipyridine units within the ligands structure enhances the cleavage activity of the complexes, probably due to $\pi$-stacking and/or hydrophobic interactions between BNPP and the zinc complexes, which can strengthen the association between the dipyridine-containing ligands and the substrate in the transient state of the hydrolytic mechanism.

The dinuclear $\mathrm{Zn}(\mathrm{II})$ complex with L1 displays a different behavior in BNPP cleavage with respect to the $\mathbf{L 2}$ one. According to Fig. (6a) and Table 2, in fact, the most active species in BNPP cleavage is the monohydroxo complex $\left[\mathrm{Zn}_{2} \mathbf{L 1}(\mathrm{OH})\right]^{3+}$, while the dihydroxo complex shows a reduced ability in BNPP hydrolysis. This behavior can be related to the fact that the two metals may act as separated binding sites for anionic substrates, such as hydroxide and BNPP. As discussed above, in the monohydroxo complex the hydroxide anion is bound to a single $\mathrm{Zn}$ (II) ion, which, in consequence, has a low tendency to interact with the anionic BNPP substrate. The second metal, not bound to hydroxide, is probably the preferred binding site for BNPP. The simultaneous presence within the same complex of both a binding site for BNPP and an adjacent $\mathrm{Zn}-\mathrm{OH}$ function could account for the hydrolytic ability of $\left[\mathrm{Zn}_{2} \mathbf{L} \mathbf{1}(\mathrm{OH})\right]^{3+}$; the $\mathrm{Zn}-\mathrm{OH}$ group can operate as simple nucleophile (b in Scheme 2) or act as a general base catalyst (c un Scheme 2) [43].

This hypothesis is corroborated by the observation that binding of the second hydroxide anion to give the $\left[\mathrm{Zn}_{2} \mathbf{L 1}(\mathrm{OH})_{2}\right]^{2+}$ complex leads to a reduced activity in BNPP hydrolysis. Most likely, binding of the second hydroxide takes place on the $\mathrm{Zn}$ (II) ion interacting with BNPP, leading to a reduced interaction of the phosphate ester with the metal and to a consequent lower activation of BNPP to the cleavage process.
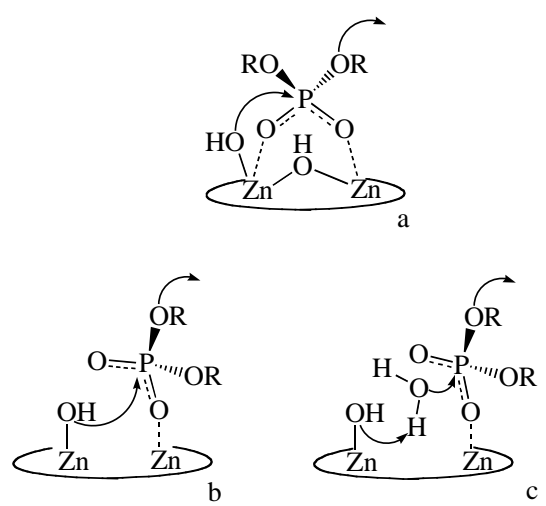

Scheme 2. Proposed mechanism for BNPP hydrolysis promoted by the dizinc complexes with $\mathbf{L 2}$ (a) and $\mathbf{L 1}$ (b and c).

Of note, the hydrolytic ability of the $\left[\mathrm{Zn}_{2} \mathbf{L 1}(\mathrm{OH})\right]^{3+}$ and $\left[\mathrm{Zn}_{2} \mathbf{L 1}(\mathrm{OH})_{2}\right]^{2+}$ complexes is lower than that found for the $\mathbf{L} 2$ complex $\left[\mathrm{Zn}_{2} \mathbf{L 2}(\mathrm{OH})_{2}\right]^{2+}$. The higher activity of the latter complex may be related to the stronger interaction of BNPP with the dizinc core of the $\mathbf{L} \mathbf{2}$ complex, as actually suggested by the ${ }^{31} \mathrm{P}$ and ${ }^{1} \mathrm{H}$ NMR measurements.

\section{CONCLUSION}

Ligands $\mathbf{L 1}$ and $\mathbf{L 2}$ afford stable dinuclear $\mathrm{Zn}(\mathrm{II})$ complexes in aqueous solutions. These complexes promote BNPP cleavage with high rate constants. Their hydrolytic ability is somewhat lower, however, than that found for the dizinc complex with macrocycle 2 , which contains two dipyridine units. Different hydrolytic mechanisms are at work in the presence of the complexes with $\mathbf{L 1}$ and $\mathbf{L 2}$, due to the different interaction mode of BNPP with the metals. In the binuclear L1 complex, the coordination sphere of the metals is more saturated by the ligand donors than in the L2 one and BNPP can interact only with a single metal, thus resulting less activated to the hydrolytic process. In consequence, the L1 complex displays a lower hydrolytic activity than the $\mathbf{L} \mathbf{2}$ one. Furthermore, the most hydrolytically active species is $\left[\mathrm{Zn}_{2} \mathbf{L 1}(\mathrm{OH})\right]^{3+}$, while the dihydroxo complex $\left[\mathrm{Zn}_{2} \mathbf{L 1}(\mathrm{OH})_{2}\right]^{2+}$ displays reduced performance. In the $\mathbf{L} 2$ complex the two metals are less coordinatively saturated by the ligand donors and, thanks to the higher flexibility of the ligand, can achieve an optimal distance to simultaneously interact with substrates, such as the simple hydroxide anion or BNPP. The bridging interaction mode of BNPP leads to a higher activation of the substrate and to an enhanced hydrolytic ability.

\section{EXPERIMENTAL SECTION}

\section{General Procedures}

UV-vis spectra were recorded at $298 \mathrm{~K}$ on a Shimadzu UV-2101PC spectrophotometer. The ${ }^{1} \mathrm{H},{ }^{13} \mathrm{C}$ and ${ }^{31} \mathrm{P}$ NMR spectra were recorded at $298 \mathrm{~K}$ on Varian UNITY 300 spectrometer. In the ${ }^{31} \mathrm{P}$ and ${ }^{1} \mathrm{H}$ NMR titrations, increasing amounts of $1 \cdot 10^{-2} \mathrm{M}$ solutions of the complexes in MeOD or 
in $\mathrm{D}_{2} \mathrm{O}$ at $\mathrm{pD} 7$ were added to a $5 \cdot 10^{-3} \mathrm{M}$ solution of BNPP. TMS or DSS were used as internal standard.

\section{Synthesis of the Ligands}

The synthetic procedure used for the synthesis of the ligands is depicted in Scheme 3. Tosylated hexamines a and b [74] and 6-(bromomethyl)-2,2'-bipyridine were synthesized as previously reported [75].
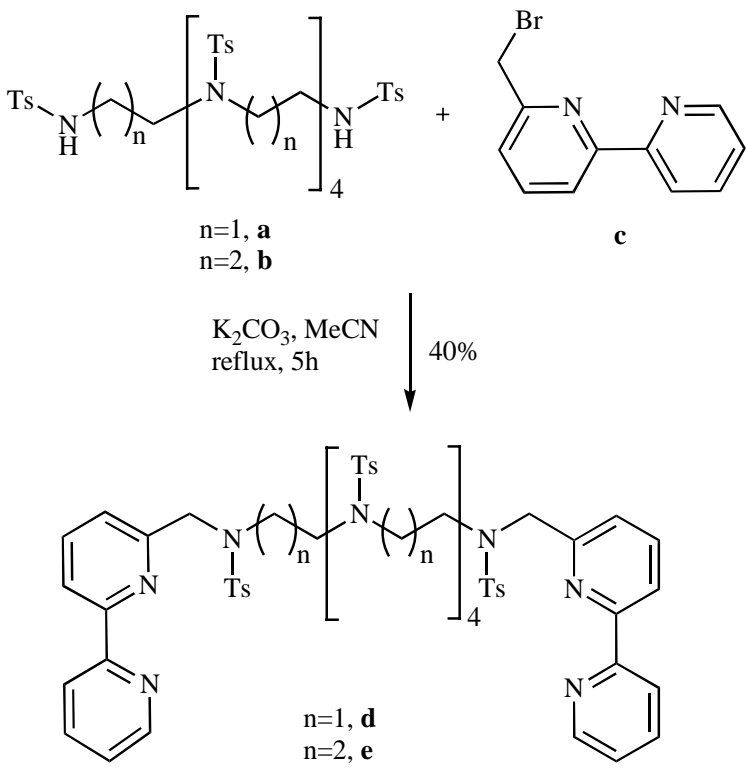

$$
\begin{array}{l|l}
\mathrm{HBr} / \mathrm{AcOH}, \mathrm{PhOH} \\
\text { reflux, overnight }
\end{array} \mid 55 \%
$$

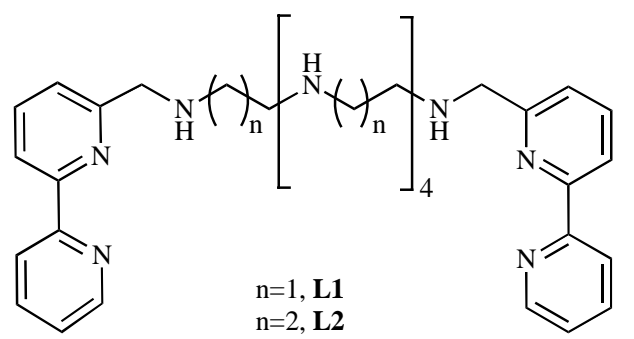

Scheme 3. Synthetic procedure for synthesis of $\mathbf{L 1}$ and $\mathbf{L 2}$.

\section{1,18-bis-[6-(2,2'-bipyridyl)-methyl]-2,5,8,11,14,17- hexatosyl-2,5,8,11,14,17-hexaaza-octadecane $(d)$}

A solution of 6-(bromomethyl)-2,2'-bipyridine (1.29 g, $5.2 \mathrm{mmol})$ in dry acetonitrile $(100 \mathrm{ml})$ was added, under a nitrogen atmosphere, to a refluxing and stirred suspension of the tosylated polyamine a $(2.90 \mathrm{~g}, 2.5 \mathrm{mmol})$ and $\mathrm{K}_{2} \mathrm{CO}_{3}$ $(3.45 \mathrm{~g}, 25 \mathrm{mmol})$ in dry acetonitrile $(100 \mathrm{ml})$ over a period of $40 \mathrm{~min}$. At the end of the addition, the mixture was kept stirring and refluxing for additional 5 hours. The suspension was filtered on Celite, washed with acetonitrile, and then the resulting solution was evaporated to dryness. The brown oil residue was purified via column chromatography on neutral alumina using a 2:1 petroleum ether/AcOEt mixture (vol:vol) as eluent. The fractions containing $\mathbf{d}$ were evaporated to dryness, affording the pure product as a yellow solid (933 mg, 25\%).
${ }^{1} \mathrm{H}-\mathrm{NMR}\left(\mathrm{CDCl}_{3}, 300 \mathrm{MHz}\right) \delta(\mathrm{ppm}) 8.65(\mathrm{~d}, \mathrm{~J}=3.9 \mathrm{~Hz}$, 2H, bpy), 8.30 (d, J=7.5 Hz, 2H, bpy), 8.13 (dd, J=7.8, 4.2 $\mathrm{Hz}, 2 \mathrm{H}, \mathrm{bpy}), 7.76$ (t, J=7.8 Hz, 2H), 7.68 (dd, J=7.8, 2.7 Hz, $2 \mathrm{H}$, bpy), 7.56-7.52 (m, 12H, Ts), 7.36-7.20 (m, $14 \mathrm{H}$, bpy+Ts), 7.13 (t, J=6.6 Hz, 2H, bpy), 4.61 (s, 4H), $3.62(\mathrm{~m}$, $4 \mathrm{H}), 3.31-3.21$ (m, 20H), 2.40, 2.36, 2.32 (s, 18H, Ts).

${ }^{13} \mathrm{C}-\mathrm{NMR}\left(\mathrm{CDCl}_{3}, 75.4 \mathrm{MHz}\right) \delta(\mathrm{ppm})$ 155.5, 148.8, $143.4,137.5,136.8,136.1,134.7,129.7,127.4,123.6,122.7$, 121.2, 119.6, 54.3, 49.3, 48.6, 21.5.

Anal Calcd. for $\mathrm{C}_{74} \mathrm{H}_{80} \mathrm{~N}_{10} \mathrm{~S}_{6} \mathrm{O}_{12}$ : C: $59.5 \%, \mathrm{H}: 5.4 \%, \mathrm{~N}$ : 9.38\%. Found: C: $58.9 \%, \mathrm{H}: 5.1 \%, \mathrm{~N}: 8.8 \%$

\section{1,23-bis-[6-(2,2'-bipyridyl)-methyl]-2,6,10,14,18,22- hexatosyl-2,6,10,14,18,22-hexaaza-tricosane $(e)$}

This product was prepared and purified by using the same procedure used for the synthesis of $\mathbf{d} .3 .24 \mathrm{~g}$ of $\mathbf{b}$ were reacted with $1.29 \mathrm{~g}$ of 6-(bromomethyl)-2,2'-bipyridine, affording product e $(3.19 \mathrm{~g}, 81 \%)$.

${ }^{1} \mathrm{H}-\mathrm{NMR}\left(\mathrm{CDCl}_{3}, 300 \mathrm{MHz}\right) \delta(\mathrm{ppm}) 8.61(\mathrm{~d}, \mathrm{~J}=6.0 \mathrm{~Hz}$, $2 \mathrm{H}$, bpy), 8.24 (d, J=8.0 Hz, 2H, bpy), 8.14 (d, J=8.2 Hz, 2H, bpy), 7.74-7.53 (m, 14H, bpy+Ts), 7.37 (d, J=7.8 Hz, 2H, bpy), 7.29-7.13 (m, 16H, bpy+Ts), $4.52(\mathrm{~s}, 4 \mathrm{H}), 3.35(\mathrm{t}$, $\mathrm{J}=6.6 \mathrm{~Hz}, 4 \mathrm{H}), 3.01(\mathrm{br}, 16 \mathrm{H}), 3.38,3.29$ (s, 18H), $1.77(\mathrm{br}$, $10 \mathrm{H})$

${ }^{13} \mathrm{C}-\mathrm{NMR}\left(\mathrm{CDCl}_{3}, 75.4 \mathrm{MHz}\right) \delta(\mathrm{ppm})$ 155.5, 148.8, 143.5-143.2, 137.5, 136.8, 134.5, 129.7, 127.4, 123.6, 122.5, 121.1, 119.5, 52.7, 48.4, 47.5, 46.7, 45.2, 28.7, 28.0, 21.3.

Anal Calcd. for $\mathrm{C}_{79} \mathrm{H}_{90} \mathrm{~N}_{10} \mathrm{~S}_{6} \mathrm{O}_{12}: \mathrm{C}: 60.67 \%, \mathrm{H}: 5.80 \%$, $\mathrm{N}: 8.96 \%$. Found: C: $61.3 \%, \mathrm{H}: 6.0 \%, \mathrm{~N}: 9.1 \%$

\section{1,18-bis-[6-(2,2'-bipyridyl)-methyl]-2,5,8,11,14,17-hexaaza- octadecane octabromohydrate (L1)}

d $(1.49 \mathrm{~g}, 1 \mathrm{mmol})$ and phenol $(16.9 \mathrm{~g}, 180 \mathrm{mmol})$ were dissolved in $\mathrm{HBr} / \mathrm{AcOH} 33 \%$ (100 $\mathrm{ml})$. The reaction mixture was kept at $90{ }^{\circ} \mathrm{C}$ under stirring for $20 \mathrm{~h}$. until a white solid formed. $100 \mathrm{ml}$ of dichloromethane were then added to complete the precipitation and the mixture was stirred for additional 1 hour. The solid was filtered and washed with dichlorometane. The resulting product was then recrystallized by using a 3:1 (v/v) EtOH:water mixture, affording $\mathbf{L 1} 8 \mathrm{HBr}$ (438 mg, 36\%).

${ }^{1} \mathrm{H}-\mathrm{NMR}\left(\mathrm{D}_{2} \mathrm{O}, \mathrm{pH}<1,300 \mathrm{MHz}\right) \delta(\mathrm{ppm}) 8.93(\mathrm{~d}, \mathrm{~J}=5.8$ $\mathrm{Hz}, 2 \mathrm{H}$, bpy), 8.74 (d, J=3.9Hz, 4H, bpy), 8.38 (d, J=7.7Hz, $2 \mathrm{H}$, bpy), 8.17 (t, J=8.0 Hz, 2H, bpy), 8.13 (dd, J=9.4,4.7 Hz, 2H, bpy), 7.74 (d, J=7,7, 2H, bpy), 4.73 (s, 4H), 3.75-3.59 $(\mathrm{m}, 20 \mathrm{H})$.

${ }^{13} \mathrm{C}-\mathrm{NMR}\left(\mathrm{D}_{2} \mathrm{O}, \mathrm{pH}<1,75.4 \mathrm{MHz}\right) \delta(\mathrm{ppm}) 152.1,147.9$, $146.5,142.1,140.5,127.6,126.3,124.7,122.9,51.1,45.2-$ 44.6.

$\begin{array}{llllll}\text { MS } & (\mathrm{ESI}) \quad(\mathrm{m} / \mathrm{z}) & 569.8 \quad(100) & (\mathrm{M}+\mathrm{H})^{+}, & 285.5 \quad(36)\end{array}$ $(\mathrm{M}+2 \mathrm{H})^{2+}$

Anal Calcd. for $\mathrm{C}_{32} \mathrm{H}_{44} \mathrm{~N}_{10} \cdot 8 \mathrm{HBr}$ : C: $31.61 \%, \mathrm{H}: 4.31 \%$, $\mathrm{N}: 11.52 \%$. Found: C: $31.9 \%, \mathrm{H}: 4.4 \%, \mathrm{~N}: 11.2 \%$

\section{1,23-bis-[6-(2,2'-bipyridyl)-methyl]-2,6,10,14,18,22- hexaaza-tricosane octabromohydrate (L2)}

This product was prepared following the same procedure used for the synthesis of L1. e $(1.56 \mathrm{~g}, 1 \mathrm{mmol})$ and phenol 
(16.9 g, $180 \mathrm{mmol})$ were dissolved in $\mathrm{HBr} / \mathrm{AcOH} 33 \%$ (100 $\mathrm{ml})$ to afford $\mathbf{L} \mathbf{2} 8 \mathrm{HBr}(683 \mathrm{mg}, 53 \%)$.

${ }^{1} \mathrm{H}-\mathrm{NMR}\left(\mathrm{D}_{2} \mathrm{O}, \mathrm{pH}<1,300 \mathrm{MHz}\right) \delta(\mathrm{ppm}) 8.90(\mathrm{~d}, \mathrm{~J}=4.8$ $\mathrm{Hz}, 2 \mathrm{H}, \mathrm{bpy}), 8.72$ (d, J=3.6 Hz, 4H, bpy), 8.36 (d, J=8.1 Hz, $2 \mathrm{H}$, bpy), 8.19 (td, J=8.1, $1.2 \mathrm{~Hz}, 2 \mathrm{H}, \mathrm{bpy}), 8.16-8.11$ (m, $2 \mathrm{H}, \mathrm{bpy}), 7.72$ (d, J=7.8 Hz, 2H, bpy), 4.65 (s, 4H), 3.40 (t, $\mathrm{J}=8.1 \mathrm{~Hz}, 4 \mathrm{H}), 3.28-3.22(\mathrm{~m}, 16 \mathrm{H}), 2.35-2.27(\mathrm{~m}, 4 \mathrm{H}), 2.18$ $2.13(\mathrm{~m}, 6 \mathrm{H})$.

${ }^{13} \mathrm{C}-\mathrm{NMR}\left(\mathrm{D}_{2} \mathrm{O}, \mathrm{pH}<1,75.4 \mathrm{MHz}\right) \delta(\mathrm{ppm}) 151.8,147.7$, $146.2,142.0,140.4,127.4,126.1,124.6,122.7,50.8,45.0-$ 44.7, 23.0.

Anal. Calcd. for $\mathrm{C}_{37} \mathrm{H}_{54} \mathrm{~N}_{10} \cdot 8 \mathrm{HBr}$ : C: $31.88 \%$, H: $4.29 \%$, $\mathrm{N}: 10.22 \%$. Found: C: $33.3 \%, \mathrm{H}: 4.8 \%, \mathrm{~N}: 10.2 \%$ (100)

MS (ESI) (m/z) $639.53(\mathrm{M}+\mathrm{H})^{+}(79), 320.49(\mathrm{M}+2 \mathrm{H})^{2+}$

\section{$\left[\mathrm{Zn}_{2} \mathrm{LI}\right]\left(\mathrm{ClO}_{4}\right)_{4} 2 \mathrm{H}_{2} \mathrm{O}(6)$}

A solution of $\mathrm{Zn}\left(\mathrm{ClO}_{4}\right)_{2} \bullet 6 \mathrm{H}_{2} \mathrm{O}(37.2 \mathrm{mg}, 0.1 \mathrm{mmol})$ in methanol $(10 \mathrm{ml})$ was slowly added to a solution of $\mathbf{L 1} \bullet 8$ $\mathrm{HBr}(61 \mathrm{mg}, 0.05 \mathrm{mmol})$ in methanol $(10 \mathrm{ml})$ under stirring. Butanol $(10 \mathrm{ml})$ was then added. The complex was obtained as a white solid by slow evaporation of the resulting solution (54 mg; 95.3\%). Anal. Calcd. for $\mathrm{C}_{32} \mathrm{H}_{48} \mathrm{~N}_{10} \mathrm{Cl}_{4} \mathrm{O}_{18} \mathrm{Zn}_{2}$ : C, 33.91; H, 4.27; N, 12.36. Found: C, 34.1; H, 4.4; N, $12.2 \%$.

\section{$\left[\mathrm{Zn}_{2} \mathrm{~L} 2\right]\left(\mathrm{ClO}_{4}\right)_{4} 2 \mathrm{H}_{2} \mathrm{O}(7)$}

This complex was obtained in $80 \%$ yield by reaction of $\mathrm{Zn}\left(\mathrm{ClO}_{4}\right)_{2} \bullet 6 \mathrm{H}_{2} \mathrm{O}$ with $\mathbf{L 2}$ in 2:1 molar ratio by using the procedure reported for $\left[\mathrm{Zn}_{2} \mathbf{L 1}\right]\left(\mathrm{ClO}_{4}\right)_{4} \bullet 2 \mathrm{H}_{2} \mathrm{O}$. Anal Calcd. for $\mathrm{C}_{37} \mathrm{H}_{58} \mathrm{~N}_{10} \mathrm{Cl}_{4} \mathrm{O}_{18} \mathrm{Zn}_{2}$ : C, 36.93; H, 4.86; N, 11.64. Found: $\mathrm{C}, 36.8 ; \mathrm{H}, 5.0 ; \mathrm{N}, 11.4 \%$.

\section{Potentiometric Measurements}

Equilibrium constants for complexation reactions with $\mathbf{L 1}$ and $\mathbf{L 2}$ were determined by means of potentiometric measurements $\left(\mathrm{pH}=-\log \left[\mathrm{H}^{+}\right]\right)$, carried out in $0.1 \mathrm{~mol} \mathrm{dm}^{-3}$ $\mathrm{NMe}_{4} \mathrm{Cl}$ at $308.1 \pm 0.1 \mathrm{~K}$, in the $\mathrm{pH}$ range $2.5-11$, by using the equipment that has been already described [76]. The reference electrode was an $\mathrm{Ag} / \mathrm{AgCl}$ electrode in saturated $\mathrm{KCl}$ solution. The glass electrode was calibrated as a hydrogen concentration probe by titrating known amounts of $\mathrm{HCl}$ with $\mathrm{CO}_{2}$-free $\mathrm{NaOH}$ solutions and determining the equivalent point by the Gran's method [77]. This allows one to determine the standard potential $\mathrm{E}^{0}$, and the ionic product of water $\left(\mathrm{pK}_{\mathrm{w}}=13.40 \pm 0.01\right)$. Ligand concentration was about $1 \times 10^{-3}$ $\mathrm{M}$, while metal concentration was in the range $2 \times 10^{-3}-5 \times 10^{-4}$ M. At least three measurements (about 100 experimental points each one) were performed for each system. The computer program HYPERQUAD [78] was used to calculate the protonation constants and the stability constants of $\mathrm{Zn}$ (II) complexes from e.m.f. data. The titration curves for each system were treated either as a single set or as separated entities without significant variations in the values of the protonation or metal complexation constants.

\section{Kinetics of bis(p-nitrophenyl)phosphate (BNPP) Hy- drolysis}

The hydrolysis rate of BNPP to give mono( $p$ nitrophenyl) phosphate (MNPP) and $p$-nitrophenate (the hydrolysis products were identified by means of ${ }^{1} \mathrm{H}$ and ${ }^{31} \mathrm{P}$
NMR spectra) in the presence of the zinc complexes with $\mathbf{L 1}$ and $\mathbf{L} \mathbf{2}$ was measured by an initial slope method monitoring the increase in $403 \mathrm{~nm}$ absorption of the $p$-nitrophenate at $308.1 \pm 0.1 \mathrm{~K}$ using the procedure reported in reference 71 . The ionic strength was adjusted to 0.1 with $\mathrm{NMe}_{4} \mathrm{NO}_{3}$. The reaction solution was maintained at $308.1 \pm 0.1 \mathrm{~K}$. MOPS (pH 6.5-8.5), TAPS (pH 7.8-9.1), CHES ( $\mathrm{pH}$ 8.6-10.1) and CAPS (pH 9.7-11.1) buffers were used $(50 \mathrm{mM})$. Freshly prepared stock solutions of the complexes $(1-10 \mathrm{mM})$ and of BNPP (1-10 mM) where used in the measurements. In a typical experiment, immediately after BNPP and the dizinc complexes with $\mathbf{L 1}$ or $\mathbf{L} \mathbf{2}$ were mixed in aqueous solutions at the appropriate $\mathrm{pH}$ (the reference experiment does not contain the $\mathrm{Zn}$ (II) complex), the UV absorption spectrum was recorded and followed generally until 5-10\% decay of BNPP. A plot of the hydrolysis rate $v s$ BNPP concentration $(1-10 \mathrm{mM})$ at a given $\mathrm{pH}$ gave a straight line, and then we determine the slope/[zinc complex] as the second order rate constants $k_{\mathrm{BNPP}}\left(\mathrm{M}^{-1} \mathrm{~s}^{-1}\right)$. In the case of $\mathbf{L 2}$, plots of the $k_{\mathrm{BNPP}}$ values as a function of the molar concentrations of the active species $\left(\left[\mathrm{Zn}_{2} \mathbf{L 2}(\mathrm{OH})_{2}\right]^{2+}\right.$ ) gave a straight line and allow to determine the $k_{\text {BNPP }}^{\prime}$ values for $100 \%$ formation of $\left[\mathrm{Zn}_{2} \mathbf{L 2}(\mathrm{OH})_{2}\right]^{2+}$. In the case of $\mathbf{L 1}$, two species, $\left[\mathrm{Zn}_{2} \mathbf{L 1}(\mathrm{OH})\right]^{3+}$ and $\left[\mathrm{Zn}_{2} \mathbf{L 1}(\mathrm{OH})_{2}\right]^{2+}$ give significant enhancement of the hydrolysis rate. Therefore, at each $\mathrm{pH}$ value, the measured second order rate constants $k_{\mathrm{BNPP}}$ are given by:

$k_{\mathrm{BNPP}}$ [total dinuclear $\mathrm{Zn}(\mathrm{II})$ complex $][\mathrm{BNPP}]=k_{1 \mathrm{BNPP}}\left[\mathrm{Zn}_{2} \mathbf{L} \mathbf{1}\right.$ $(\mathrm{OH})]^{3+}[\mathrm{BNPP}]+k_{2 \mathrm{BNPP}}\left[\mathrm{Zn}_{2} \mathbf{L} \mathbf{1}(\mathrm{OH})_{2}\right]^{2+}[\mathrm{BNPP}]$

The $k_{1 \mathrm{BNPP}}$ and $k_{2 \mathrm{BNPP}}$ values were calculated by least squares fitting of the $k_{\mathrm{BNPP}}$ values collected at different $\mathrm{pHs}$. Plots of the $k_{1 \mathrm{BNPP}}$ and $k_{2 \mathrm{BNPP}}$ values vs $\left[\mathrm{Zn}_{2} \mathbf{L 1}(\mathrm{OH})\right]^{3+}$ and $\left[\mathrm{Zn}_{2} \mathbf{L 1}(\mathrm{OH})_{2}\right]^{2+}$ percentages, respectively, gave straight lines and allows one to determine the rate constants $k^{\prime}{ }_{\mathrm{BNPP}}$ at $100 \%$ formation of $\left[\mathrm{Zn}_{2} \mathbf{L 1}(\mathrm{OH})\right]^{3+}$ and $\left[\mathrm{Zn}_{2} \mathbf{L 1}(\mathrm{OH})_{2}\right]^{2+}$,

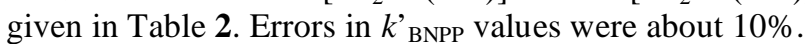

\section{REFERENCES}

[1] Kim, E. E.; Wyckoff, H. W. J. Mol. Biol., 1991, 218, 449

[2] Coleman, J. E. Ann. Rev. Biophys. Biomol. Struct., 1992, 21, 441.

[3] Lipscomb, W. N.; Sträter, N. Chem. Rev., 1996, 96, 2375.

[4] Sträter, N.; Lipscomb, W. N.; Klabunde, T.; Krebs, B. Angew.Chem. Int. Ed. Engl., 1996, 35, 2024.

[5] Zinc Enzymes; Bertini, I.; Luchinat, C.; Marek, W.; Zeppezauer, M.; (Eds).; Birkauser: Boston, MA, 1986.

[6] Wilcox, D. E. Chem. Rev., 1996, 96, 2435.

[7] Steinhagen, H.; Helmchem, G. Angew. Chem. Int. Ed. Engl., 1996, 35, 2339.

[8] Dodgson, S. J.; Tashian, R. E.; Gros, G.; Carter, N. D. The Carbonic Anhidrases; Plenum Press: New York, 1991.

[9] Christianson, D. W. Adv. Protein Chem., 1991, 41, 281.

[10] Silverman, D. N.; Lindskog, S. Acc. Chem. Res., 1988, 21, 30

[11] Holz, R. C. Coord. Chem. Rev., 2002, 232, 5.

[12] Izatt, R. M.; Pawlak, K.; Bradshaw, J. S.; Bruening, R. L. Chem. Rev., 1995, 95, 2529.

[13] Lehn, J. -M. Supramolecular Chemistry: Concepts and Perspectives; VCH: New York, 1995.

[14] Lindoy, L. F. The Chemistry of Macrocyclic Ligand Complexes; Cambridge University Press: Cambridge, UK, 1992.

[15] Lindoy, L. F. Pure Appl. Chem., 1997, 69, 2179.

[16] Raidt, R.; Neuburger, M.; Kaden, T. A. Dalton Trans., 2003, 1292.

[17] Kaden, T. A. Coord. Chem. Rev., 1999, 190-192, 371

[18] Nelson, J.; McKee, V.; Morgan, G. Progr. Inorg. Chem., 1998, 47, 167.

[19] Bencini, A.; Bianchi, A.; Paoletti, P.; Paoli, P. Coord. Chem. Rev., 1992, 120,51 
[20] Fry, F. H.; Moubaraki, B.; Murray, K. S.; Spiccia, L.; Warren, M.; Skelton, B. W.; White, A. H. J. Chem. Soc. Dalton Trans., 2003, 866.

[21] Brooker, S. D. Coord. Chem. Rev., 2001, 222, 3.

[22] Lamarque, L.; Navarro, P.; Miranda, C.; Aran, V. J.; Ochoa, C.; Escartí, F.; García-España, E.; Latorre, J.; Luis, S. V.; Miravet, J. F. J. Am. Chem. Soc., 2001, 123, 10560.

[23] Hortala, M. A.; Fabbrizzi, L.; Marcotte, N.; Stomeo, F.; Taglietti, A. J. Am. Chem. Soc., 2003, 125, 20-21.

[24] Ambrosi, G.; Dapporto, P.; Formica, M.; Fusi, V.; Giorgi, L.; Guerri, A.; Micheloni, M.; Paoli, P.; Pontellini, R.; Rossi, P. Chem. Eur. J., 2003, 9,800 .

[25] Dapporto, P.; Formica, M.; Fusi, V.; Giorgi, L.; Micheloni, M.; Paoli, P.; Pontellini, R.; Rossi, P. Inorg. Chem., 2001, 40, 6186.

[26] Chand, D. K.; Schneider, H.-J.; Bencini, A.; Bianchi, A.; Giorgi, C.; Ciattini, S.; Valtancoli, B. Chem. Eur. J., 2000, 6, 4001.

[27] Adams, H.; Clunas, S.; Fenton, D. E.; Spey, S. E. Dalton Trans., 2003, 625 .

[28] Ōkawa, H.; Furutachi, H.; Fenton, D. E. Coord. Chem. Rev., 1998, $174,51$.

[29] Subat, M.; Woinaroschy, K.; Anthofer, S., Malterer, B., Konig, B. Inorg. Chem., 2007, 46, 4336.

[30] Boerner, L. J. K.; Zaleski, J. M. Curr. Opin. Chem. Biol., 2005, 9, 135.

[31] Schneider, H.-J.; Yatsimirsky, A. in Metal Ion in Biological Systems, Sigel H.; Sigel, A. Eds.; Marcel Dekker: New York, 2003; Vol. 40, pp. 369-462.

[32] Komiyama, M. In Metal Ions in Biological Systems, Sigel, H.; Sigel, A. Eds.; Marcel Dekker: New York, 2003; Vol. 40, pp 463475.

[33] Blasko, A.; Bruice, T. C. Acc. Chem. Res., 1999, 32, 475 and refs. therein.

[34] Hegg, E. L.; Burstyn, J. N. Coord. Chem. Rev., 1998, 173, 133 and refs. therein.

[35] Krämer, R.; Coord. Chem. Rev., 1999, 182, 243 and refs. therein.

[36] Kimura, E.; Curr. Opin. Chem. Biol., 2000, 4, 207.

[37] Aoki, S.; Kimura, E. Rev. Mol. Biotech., 2002, 90, 129 and refs. therein.

[38] Molenveld, P.; Engbersen, J. F. J.; Reinhoudt, D. N. Chem. Soc. Rev., 2000, 29, 75.

[39] Williams, N. H.; Takasaki, B.; Wall, M.; Chin, J. Acc. Chem. Res., 1999, 32, 485.

[40] Liu, C.; Wang, M.; Zhang, T.; Sun, H. Coord. Chem. Rev., 2004, 248,147 and refs. therein.

[41] Parkin, G. Chem. Rev., 2004, 104, 699.

[42] Weston, J. Chem. Rev., 2005, 105, 2151.

[43] Chin, J. Curr. Opin. Chem. Biol., 1997, 1, 514.

[44] Scrimin, P.; Baltzer, L. Curr. Opin. Chem. Biol., 2005, 9, 620.

[45] Mancin, F.; Scrimin, P.; Tecilla, P.; Tonellato, U. Chem. Commun., 2005, 20, 2540

[46] Bazzicalupi, C.; Bencini, A.; Bianchi, A.; Fusi, V.; Giorgi, G.; Paoletti, P.; Valtancoli, B.; Zanchi, D. Inorg. Chem., 1997, 36, 2784.

[47] Bazzicalupi, C.; Bencini, A.; Berni, E.; Bianchi, A.; Fedi, V.; Fusi, V.; Giorgi, G., Paoletti, P.; Valtancoli, B. Inorg. Chem., 1999, 38, 4115 .

[48] Bazzicalupi, C.; Bencini, A.; Berni, E.; Bianchi, A.; Giorgi, G.; Paoletti, P.; Valtancoli, B. Inorg. Chem., 1999, 38, 6323.
[49] Arca, M.; Bencini, A.; Berni, E.; Caltagirone, C.; Devillanova, F. A.; Isaia, F.; Garau, A.; Giorgi, G.; Lippolis, V.; Perra, A.; Tei, L.; Valtancoli, B. Inorg. Chem., 2003, 42, 6929.

[50] Kimura, E.; Koike, T. Inorg. Chem., 1997, 44, 229.

[51] Kimura, E.; Koike, T. J. Chem. Soc. Chem. Commun., 1998, 1495.

[52] Rossi, P.; Felluga, F.; Tecilla, P.; Formaggio, F.; Crisma, M.; Toniolo, C.; Scrimin, P. Biopolymers, 2000, 55, 496.

[53] Sissi, C.; Rossi, P.; Felluga, F.; Formaggio, F.; Palumbo, M.; Tecilla, P.; Toniolo, C.; Scrimin, P. J. Am. Chem. Soc., 2001, 123, 3169.

[54] Boseggia E.; Gatos M.; Lucatello L.; Mancin F.; Moro S.; Palumbo M.; Sissi C.; Tecilla P.; Tonellato U.; Zagotto G. J. Am. Chem. Soc., 2004, 126, 4543 .

[55] Sissi, C.; Mancin, F.; Palumbo, M.; Scrimin, P.; Tecilla, P.; Tonellato, U. Nucleos. Nucleot. Nucleic Acids, 2000, 19, 1265.

[56] Iranzo, O.; Kovalevsky, A. Y.; Morrow, J. R.; Richard, J. P. J. Am. Chem. Soc., 2003, 125, 1988.

[57] Iranzo, O.; Elmer, T.; Richard, J. P.; Morrow, J. R. Inorg. Chem., 2003, 42, 7737.

[58] Yang, M.-Y.; Richard, J. P.; Morrow, J. R. Chem. Commun., 2003, 2832.

[59] Kong, D.; Martell, A. E.; Reibenspies, J. Inorg. Chim. Acta, 2002, 333,7 .

[60] Leivers, M.; Breslow, R. Bioorg. Chem., 2001, 29, 345-356,

[61] Schneider, H.-J.; Hettich, R. J. Am. Chem. Soc., 1997, 119, 5638.

[62] Bazzicalupi, C.; Bencini, A., Bianchi, A.; Borsari, L.; Danesi, A.; Giorgi, C.; Lodeiro, C.; Mariani, P.; Pina, F.; Santarelli, S.; Tamayo, A.; Valtancoli, B. Dalton Trans., 2006, 4000.

[63] Nihan, F.; Akkaya, M. S.; Akkaya E. U. J. Mol. Catal A Chem. 2001, 165, 291-294.

[64] Li, S.-A.; Yang, D.-X.; Li, D.-F.; Huang, J.; Tang, W.-X. New J. Chem., 2002, 26, 1831.

[65] Li, S-A; Li, D. F.; Yang, D.-X.; Li, Y.-Z.; Huang, J.; Yu, K.-B.; Tang, W.-X. Chem. Commun., 2003, 7, 880.

[66] Yang, D.-X.; Li, S.-A.; Li, D.-F; Xia, J.; Yu, K.-B.; Tang, W.-X.; J. Chem. S., Dalton Trans., 2002, 4042.

[67] Kimura, E.; Kikuchi, M.; Kitamura, H.; Koike, T. Chem. Eur. J., 1999, 5, 3113 .

[68] Aoki, S.; Sugimura, C.; Kimura, E. J. Am. Chem. Soc., 1998, 120 , 10094.

[69] Gajda, T.; Kramer, R.; Jancso, A. Eur. J. Inorg. Chem., 2000, 1635.

[70] Jancso, A.; Mikkola, S.; Lönnberg, H.; Hegetschweiler, K.; Gaida, T. Chem. Eur. J., 2003, 9, 5404-5415.

[71] Bazzicalupi, C.; Bencini, A.; Berni, E.; Bianchi, A.; Fornasari, P.; Giorgi, C.; Valtancoli, B. Inorg. Chem., 2004, 43(20), 6255-6265.

[72] Bencini, A.; Bianchi, A.; Garcia-Espana, E.; Micheloni, M.; Ramirez, J.A. Coord. Chem. Rev., 1999, 188, 97.

[73] Arnaud-Neu, F.; Asfari, Z.; Soulev, V.; J. Chem. Soc. Perkin Trans. II, 2000, 495.

[74] Bazzicalupi, C.; Biagini, S.; Bencini, A.; Faggi, E.; Giorgi, C.; Matera, I.; Valtancoli, B. Chem. Commun., 2006, 4087.

[75] Newkome, G. R.; Gupta, V. K.; Fronczek, F. R.; Inorg. Chem., 1983, 22, 171.

[76] Lodeiro, C.; Parola, A. J.; Pina, F.; Bazzicalupi, C.; Bencini, A.; Bianchi, A.; Giorgi, C.; Masotti, A.; Valtancoli, B. Inorg. Chem., 2001, 40, 2968.

[77] Gran, G. Analyst, 1952, 77, 661.

[78] Gans, P.; Sabatini, A.; Vacca, A. J. Chem. Soc. Dalton Trans., 1985, 1195. 